\title{
Trial Separation
}

National Cancer Institute

\section{Source}

National Cancer Institute. Trial Separation. NCI Thesaurus. Code C150750.

An indication that a couple has informally separated. 